\title{
The immunological component of the cellular inflammatory infiltrate in bronchiectasis
}

\author{
J R LAPA E SILVA, J A H JONES, P J COLE, L W POULTER
}

From the Host Defence Unit, Department of Thoracic Medicine, National Heart and Lung Institute, Brompton Hospital, and the Academic Department of Immunology, Royal Free Hospital and School of Medicine, London

ABSTRACT Immunohistological analysis of bronchial biopsy specimens from nine patients with bronchiectasis and four control subjects was performed with a panel of monoclonal antibodies selected to show lymphocyte and macrophage subsets and signs of cellular activation. The cells taking part in the inflammatory response in the bronchial wall of patients with bronchiectasis were almost exclusively mononuclear cells, most of them T lymphocytes. B lymphocytes were observed in biopsy specimens from only two out of nine patients. $\mathrm{CD} 8^{+} \mathrm{T}$ cells outnumbered $\mathrm{CD} 4^{+}$cells in all patients in a ratio ranging from 2:1 to 10:1. Most $T$ lymphocytes also strongly expressed CD7 antigen and a proportion of them expressed HLA-DR. Most of the lymphocytic infiltration occurred just beneath the basement membrane of the epithelium, though intraepithelial and submucosal infiltration was also seen. Non-lymphoid mononuclear cells expressing the phenotype of dendritic cells and macrophages were found dispersed throughout the infiltrate, most of them expressing HLA-DR. These observations support the hypothesis that cell mediated immunological reactions contribute to the inflammation associated with bronchiectasis.

\section{Introduction}

Bronchiectasis is a chronic disease characterised by irreversible dilatation of the bronchi and, in most cases, by persistent production of purulent sputum. Since the advent of antibiotics the most florid saccular manifestations of the disease have been less frequent, but a progressive form of disease in young adults is now well recognised.'

Understanding of the pathogenesis of the disease has increased in recent years, ${ }^{2}$ but many aspects remain obscure. Data are accruing to support the hypothesis of Cole and coworkers ${ }^{1}$ that the chronic inflammatory host response to microbial colonisation in bronchiectasis contributes substantially to progressive bronchial damage. Although this persistent host inflammatory response in the bronchial wall and surrounding lung tissue has potential benefits (for example, in the resolution of acute infection), these may be outweighed by the damage it causes, leading ultimately to scarring and shrinkage of the lung and cardiorespiratory failure. The histological pattern in bronchiectasis is seen principally as an infiltration of mononuclear cells into the affected area of the bron-

Address for reprint requests: Professor P J Cole, Host Defence Unit, Department of Thoracic Medicine, National Heart and Lung Institute, Brompton Hospital, Dovehouse Street, London SW3 6LY. chial wall. The intensity of infiltration varies from rather dispersed mononuclear cells in milder cases to striking collections of lymphoid follicles and nodules in the most advanced cases, sometimes completely obstructing the most peripheral airways. ${ }^{3}$

The cellular components of the inflammatory host response have been investigated in certain lung diseases-for example, sarcoidosis, ${ }^{45}$ cryptogenic fibrosing alveolitis ${ }^{6}$-and notably in rheumatoid arthritis, ${ }^{7}$ but not so far in bronchiectasis. We have used immunohistochemical methods to ascertain whether immunocompetent cells are present in affected bronchial tissues of patients with bronchiectasis.

\section{Methods}

Tissue from nine patients with radiographically $\approx$ proved bronchiectasis were obtained at lobar resection $N$ or by bronchial biopsy during fibreoptic bronchoscopy. Six of the nine patients had postinfective bronchiectasis and the other three patients had bronchiectasis associated with other conditions (table 1). Samples of affected airways were dissected from surgical specimens. Endoscopic biopsy specimens were taken from segmental or subsegmental bronchi of radiologically affected lobes. The biopsies were intended to obtain samples of bronchial mucosa and submucosa. The average size of the specimens was 1$2 \mathrm{~mm}^{3}$. Control tissue was obtained from four patients 
Table 1 Characteristics of patients with bronchiectasis and controls

\begin{tabular}{|c|c|c|c|c|}
\hline \multirow[b]{2}{*}{ Patient No } & \multirow[b]{2}{*}{ Age, sex } & \multirow[b]{2}{*}{ Main diagnosis (duration ( $y$ ) of symptoms) } & \multicolumn{2}{|l|}{ Tissue obtained } \\
\hline & & & at & from \\
\hline \multicolumn{5}{|c|}{ Bronchiectasis } \\
\hline $\begin{array}{l}1 \\
2 \\
3 \\
4 \\
5 \\
6 \\
7 \\
8 \\
9\end{array}$ & $\begin{array}{l}20, \mathrm{~F} \\
40, \mathrm{M} \\
37, \mathrm{M} \\
28, \mathrm{~F} \\
43, \mathrm{~F} \\
39, \mathrm{M} \\
60, \mathrm{M} \\
66, \mathrm{~F} \\
43, \mathrm{~F}\end{array}$ & $\begin{array}{l}\text { Cystic fibrosis (20) } \\
\text { Young's syndrome (39) } \\
\text { Postinfective bronchiectasis (30) } \\
\text { Postinfective bronchiectasis (6) } \\
\text { Postinfective bronchiectasis (42) } \\
\text { Ulcerative colitis (18) } \\
\text { Postinfective bronchiectasis (55) } \\
\text { Postinfective bronchiectasis (9) } \\
\text { Postinfective bronchiectasis (38) }\end{array}$ & $\begin{array}{l}\text { Necropsy } \\
\text { Bronchoscopic* biopsy } \\
\text { Lobectomy } \\
\text { Lobectomy } \\
\text { Bronchoscopic biopsy } \\
\text { Lobectomy } \\
\text { Lobectomy } \\
\text { Lobectomy } \\
\text { Lobectomy }\end{array}$ & $\begin{array}{l}\text { LLL } \\
\text { LLL } \\
\text { ML } \\
\text { LLL } \\
\text { LLL } \\
\text { LLL } \\
\text { LLL } \\
\text { LLL } \\
\text { LLL }\end{array}$ \\
\hline \multicolumn{5}{|l|}{ Controls } \\
\hline $\begin{array}{l}\text { A } \\
\text { B } \\
\text { C } \\
\text { D }\end{array}$ & $\begin{array}{l}73, M \\
43, M \\
67, M \\
29, F\end{array}$ & $\begin{array}{l}\text { Pneumonia }(1 / 12) \\
\text { Carcinoma }\left(1 \frac{1}{2}\right) \\
\text { Pneumonia }(1 / 12) \\
\text { Pneumonia }(1 / 12)\end{array}$ & $\begin{array}{l}\text { Bronchoscopic biopsy } \\
\text { Lobectomy } \\
\text { Bronchoscopic biopsy } \\
\text { Bronchoscopic biopsy }\end{array}$ & $\begin{array}{l}\text { RUL } \\
\text { LLL } \\
\text { RUL } \\
\text { LLL }\end{array}$ \\
\hline
\end{tabular}

*Fibreoptic bronchoscopy.

LLL — left lower lobe; ML -middle lobe; RUL—right upper lobe.

without bronchiectasis (three pneumonia, one carcinoma) (table 1) by bronchial biopsy at clinically indicated fibreoptic bronchoscopy (three cases) or at resection for bronchial carcinoma (one case). No other disease was present in the control cases. All patients had previously given written consent for the procedures and the study had the approval of the ethics committee of the Brompton Hospital.

All tissue samples were covered in Tissue-Tek Optimal Cutting Temperature Compound (Miles Laboratories, Kankakee, Illinois), orientated on cork discs, snap frozen in isopentane cooled by liquid nitrogen, and stored at $-70^{\circ} \mathrm{C}$. Cryostat sections of $6 \mu \mathrm{m}$ were placed on microscope slides coated with poly-L-lysine, air dried for two hours, fixed in chloroform-acetone (1:1) for 10 minutes, wrapped in cling film (Handywrap, Payne Scientific, Berks), and stored at $-20^{\circ} \mathrm{C}$ until use.

Some sections were stained with conventional histological stains - haematoxylin and eosin, toluidine blue, and Miller's van Gieson stain (for elastin). Other sections were examined with a panel of murine monoclonal antibodies for specific surface antigens on lymphocytes and macrophage like cells (table 2). The reaction of the antibodies RFTmix, RFT8, RFBmix, RFD1, RFD7, and RFDR was revealed by immunoperoxidase staining for mouse immunoglobulin with the use of 3'3'-diaminobenzidine (Sigma Chemical Company, St Louis, Missouri) as the disclosing agent. The immunofluorescence studies used heavy chain specific anti-mouse antisera conjugated to fluorescein isothiocyanate and tetramethyl rhodamine isothiocyanate (Southern Biotechnology Associates, Alabama) ${ }^{89}$ The use of a combination of two monoclonal antibodies with different heavy chain specificities allowed study of the relative proportions of cells in the section expressing either or both of the surface markers concerned. At least three sections of each specimen of bronchiectatic and control tissues were stained with any one of the monoclonal antibodies and techniques described.

Double immunofluorescence was used to investigate the CD4:CD8 (Leu3a:RFT8) ratios in the bronchial wall and the expression of $\mathrm{CD} 7$ on $T$ lymphocytes (RFTmix:RFT2). Three sections of each sample were stained with both monoclonal antibodies

Table 2 Panel of monoclonal antibodies

\begin{tabular}{lllll}
\hline Cluster designation & Name & Specificity in normal tissues & Source & Reference \\
\hline CD4 & Leu3a & T helper cells & Becton Dickinson & 17 \\
CD7 & RFT2 & Pan T cells (strongly expressed by blasts) & RFHSM & 18 \\
CD5, 8, & RFTmix & All T cells & RFHSM & 19 \\
CD8 & RFT8 & T suppressor-cytotoxic cells & RFHSM & 19 \\
CD23, 24 & RFBmix & Panperipheral B cells & RFHSM & 20 \\
- & RFD1(*) & Dendritic cells & RFHSM & 21 \\
- & RFD7 & Mature macrophages, & RFHSM & 23 \\
\hline
\end{tabular}

*RFD1 precipitated a 28-33 Kd molecule from appropriate cell lines but its expression is restricted in immunohistological stains to the cells shown above. It is, for example, not expressed on Langerhans cells. It therefore reacts with an epitope on a class II major histocompatibility (MHC) molecule that is only "visible" on a restricted population of cells or when a specific function is being expressed.

RFHSM-Royal Free Hospital School of Medicine. 
and the numbers of positive cells counted in all areas. At least 100 cells were counted in each compartment and the results (in the case of RFTmix/CD7) expressed as the percentages of double labelled cells. Proportions of CD4:CD8 cells were expressed as ratios. Sections of tonsil resection specimens were used as positive controls and consecutive sections of the bronchial tissue under study as negative controls. Immunofluorescent staining was read with a Zeiss fluorescence microscope.

Immunoperoxidase stained sections were read separately by two observers and scored semiquantitatively in five categories: no positive cells $=0$; very few positive cells $=1$; few positive cells $=2$; a moderate number of positive cells $=3$; many positive cells $=4$. At least three different stained sections from the same block were assessed independently by the two observers; the reproducibility of the scores was $84 \%$. The results are presented in terms of the mean (SD) score assigned after observation of sections from all specimens within each group. Student's $t$ test for nonpaired data was used for the comparison of the frequency of positive cells in the two groups of patients.

The frequency of positive cells was analysed in three compartments of the bronchial wall: epithelium, lamina propria, and submucosa.

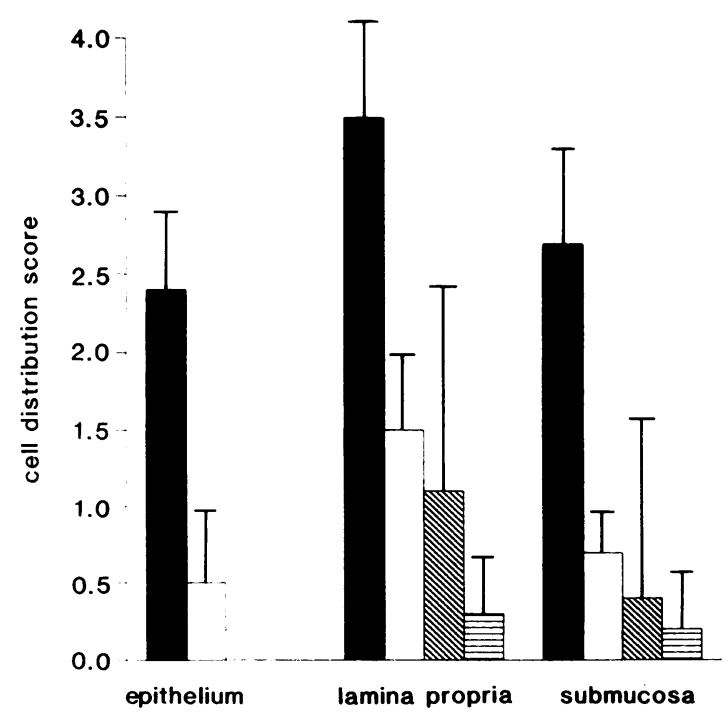

Fig 1 Relative frequency of $T$ lymphocytes in bronchiectatic (D) and control ( $\square$ ) samples and of B lymphocytes in bronchiectatic (N) and control (․ㅜㄹ) samples in epithelium, lamina propria, and submucosa. For scoring see under "Methods."

\section{Results}

\section{CONVENTIONAL HISTOLOGY}

The histological appearances of the bronchiectatic $\frac{\bar{D}}{\bar{D}}$ tissue was classified according to the method of $\frac{\pi}{\widehat{T}}$ Whitwell ${ }^{3}$ as showing mild or moderate follicular $\AA$ bronchiectasis. No specimens showed severe follicular के bronchiectasis or any of the other forms (saccular and $\vec{\circ}$ atelectatic bronchiectasis) described by Whitwell. The epithelium was relatively well preserved, with few $\vec{\omega}$ areas of disruption. Mononuclear cells were seen to have infiltrated the cells of the pseudostratified epi- $x$ thelium. The smooth muscle was intact, but the elastic $\stackrel{+}{+}$ layer showed considerable damage in the more advan- $\infty$ ced cases. The submucosal glands were enlarged, but 8 there was none of the destruction seen in severe cases. ${ }^{3} 0$ Some specimens showed increased vascularity, mainly in the submucosa. The cartilage was well preserved. In one tissue nests of giant epithelioid cells were present in the deeper stroma of the bronchial wall.

Infiltration by mononuclear cells was the most $\stackrel{\text { 嘋 }}{\circ}$ striking and constant feature, varying from a mild $\vec{\varphi}$ dispersed infiltrate to massive numbers of cells sometimes arranged in a follicular pattern and mainly in the lamina propria. There were relatively few polymorphonuclear neutrophils in the bronchial wall, $\frac{\partial}{\partial}$ though many were present in the bronchial lumen along with cellular debris and mucus.

The histological appearance of one control tissue was not entirely normal, showing some cell infiltration and gland hyperplasia, compatible with very mild chronic inflammation (this was from a patient with carcinoma).

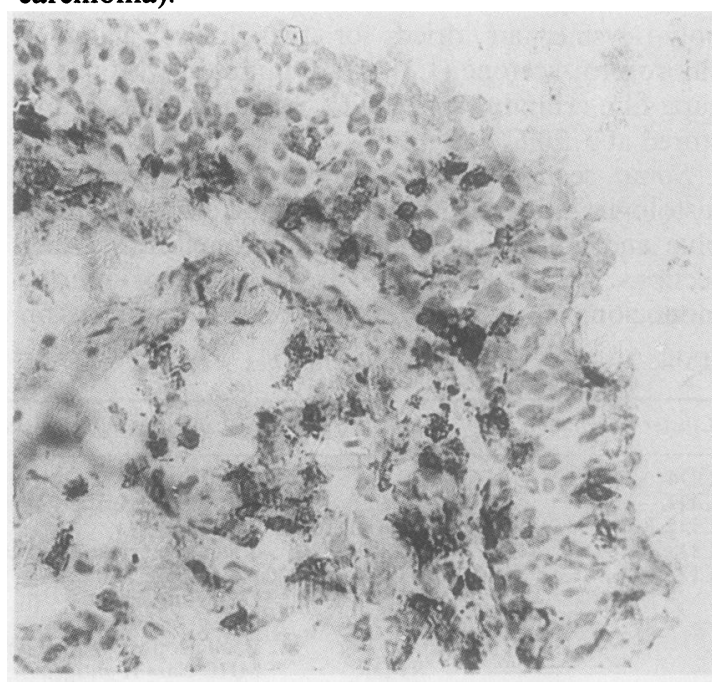

Fig 2 Accumulation of T lymphocytes under the bronchial basement membrane and infiltrating the bronchial epithelium in a specimen from a patient with bronchiectasis. (Immunoperoxidase stain.) 


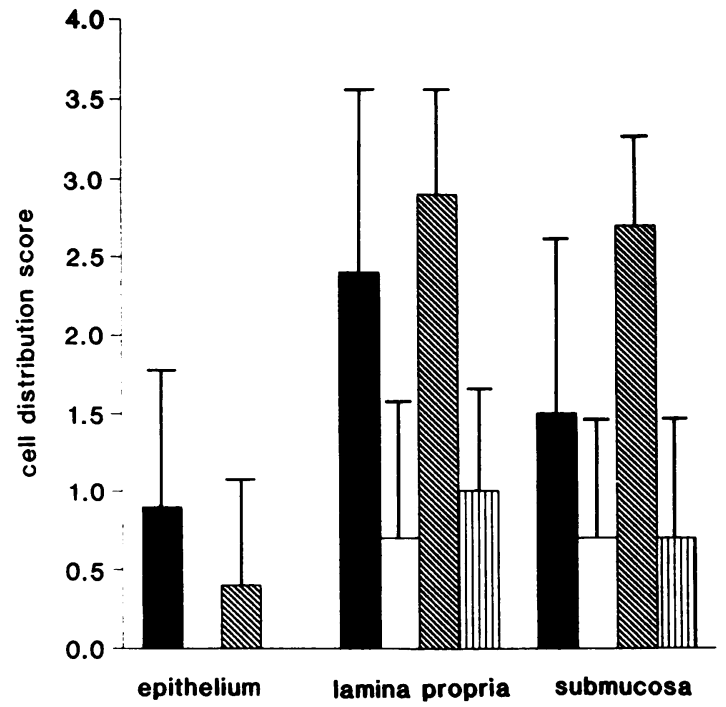

Fig 3 Relative frequency of $\mathrm{RFDI}^{+}$cells in bronchiectatic (D) and control ( $\square$ ) samples and of $\mathrm{RFDT}^{+}$cells in bronchiectatic $(\mathbb{N})$ and control (眚) samples in the epithelium, lamina propria, and submucosa. For scoring see under "Methods."

\section{IMMUNOHISTOLOGY}

\section{Lymphocytes (fig 1)}

The most striking feature was the large number of $T$ lymphocytes stained with the RFTmix monoclonal antibody infiltrating all compartments (epithelium, lamina propria, and submucosa) of the bronchiectatic tissue. This accounted for most of the mononuclear cells present in the chronic inflammatory reaction. This marker was the only one to show a significant difference between bronchiectatic and control groups $(p<0.01)$ in the three areas of the bronchial wall. Differences in the distribution of other cell types were apparent in some but not all areas of the tissue (see below).

T lymphocytes had infiltrated the epithelium of all patients, but the predominant distribution was in the lamina propria (fig 2). These $T$ cells were often arranged just below the basement membrane of the epithelium, sometimes isolated but usually packed in clusters of cells. In the submucosa they were mainly around glands and vessels. In contrast, $B$ lymphocytes were seen in only two specimens and no significant differences were found between control subjects and patients with bronchiectasis. The bronchial wall of one patient showed clusters of B lymphocytes staining for RFB mix packed in huge follicles in the lamina propria and submucosa. The bronchial wall of a second subject showed a group of B cells (mixed with T cells) just beneath the basal layer of the epithelium, possibly representing bronchus associated lymphoid tissue.

The control tissues differed mainly in the number of

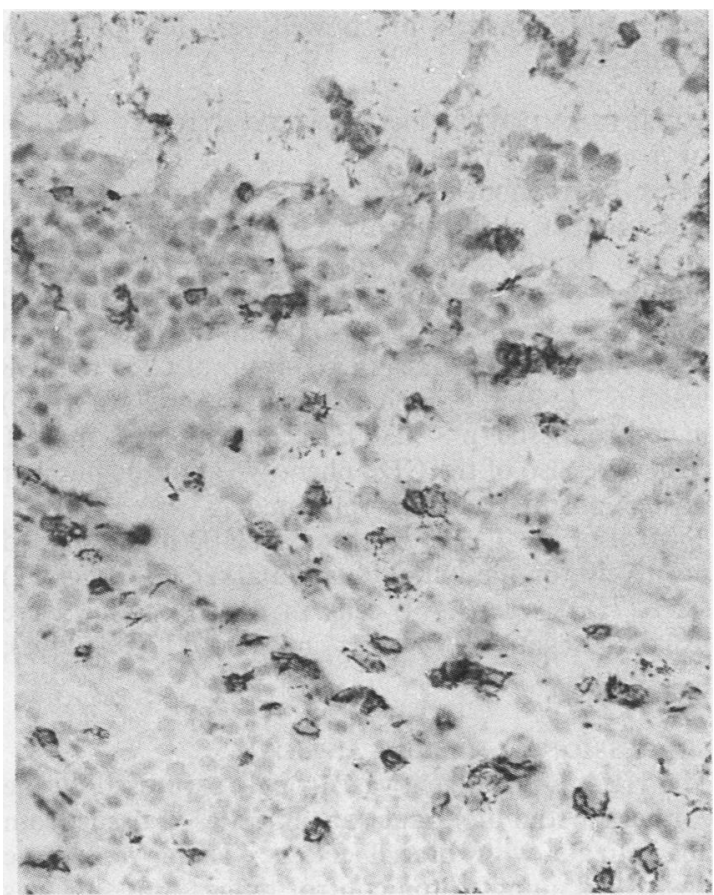

Fig 4 Diffusely distributed $C D 8^{+} T$ cells adjacent to and within the epithelium of the bronchial wall of a specimen from a patient with bronchiectasis. (Immunoperoxidase stain.)

T cells staining for RFTmix. There were far fewer such positively stained cells than in the bronchiectatic tissues and they were dispersed mainly in the epithelium and lamina propria. There were a few B lymphocytes in one section only.

\section{Macrophage like cells (fig 3).}

Dendritic cells staining for RFD1 were present in all tissues except those from one patient. The predominant distribution was in the lamina propria, where they were sometimes found in groups but were usually isolated. The tissue from one patient showed many cells staining for RFD1 in the alveolar area contiguous with the bronchial wall. Only the numbers of RFD1 ${ }^{+}$ cells present in the lamina propria were significantly different when the bronchiectatic and control groups were compared ( $p<0.01)$.

Mature macrophages staining for RFD7 were present in tissue from all patients. These cells were not confined to any particular area and were usually isolated, but in two patients there were groups of positively stained cells in the deeper stroma of the bronchus. The frequency of positively stained cells was greater in tissue from the patients than from the control subjects in the lamina propria and submucosa $(p<0.01)$ but not in the epithelium $(p=0.29)$. The control tissues either were negative for both RFD1 
and RFD7 markers or showed very few positively stained cells.

\section{SUBSETS AND MARKERS OF ACTIVATION}

OF T LYMPHOCYTES

Most T lymphocytes were of the CD8 subset (fig 4). The number of T cells expressing the CD8 (RFT8) marker nearly always (in $7 / 9$ cases) exceeded the number of cells expressing CD4 (Leu3a) in all compartments of the bronchial wall in patients with bronchiectasis. The mean (SD) ratio of CD4 to CD8 was 1:6.7 (3.2) in bronchiectatic tissue and 1:2.5 (0.6) in control tissue $(p<0.01)$. In control tissues most $T$ cells were also of the CD8 phenotype but the number of such positive cells was very small.

Most of the T cells in bronchiectatic tissue stained positively for the lymphoblast marker CD7 (RFT2) $(85 \%(7 \%))$ whereas $\mathrm{T}$ cells in control tissue were usually negative for this marker $(27.5 \%(20 \%)$; $\mathrm{p}<0.01)$.

\section{EXPRESSION OF HLA-DR ANTIGEN}

The HLA-DR antigen was strongly expressed by the epithelium and mononuclear infiltrates in tissue from all patients with bronchiectasis. There was some positive staining in the control tissues, but this was irregularly distributed in the epithelium, with very low expression in cells of the lamina propria and submucosa.

\section{Discussion}

Whitwell's study of the pathology of bronchiectasis emphasised chronic infiltration of mononuclear cells as the common histological pattern in all types of this disease. Immunohistochemical methods have been used to identify the different kinds of cells present in this chronic inflammation, their degree of activation, some of their functions and their interrelationship. Although our knowledge of mucosal immunity has increased in the last few years, many mechanisms are still poorly understood. ${ }^{10}$ In healthy tissues of the tracheobronchial tree lymphocytes are present in the intraepithelial compartment and lamina propria, but their phenotype has been little studied. Bronchus associated lymphoid tissue, a follicular collection containing mainly B lymphocytes overlaid by specialised epithelium, is distinct and usually present in areas of airflow turbulence, probably functioning mainly in the sampling of antigen. ${ }^{11}{ }^{12}$

This study shows that the predominant cells present in the inflammatory infiltrates of bronchiectasis are immunologically active $T$ lymphocytes. Few B lymphocytes were present and these were mainly restricted to the areas of follicle formation. This may be partly due to the fact that our study was restricted to more

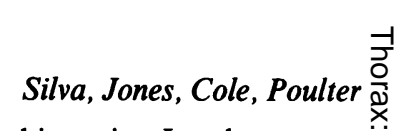

localised forms of bronchiectasis. In the severe follicular forms of the disease the proportions may be $\stackrel{\bar{O}}{\rightarrow}$ different.

The presence in bronchiectatic tissue of cells with a 듬 dendritic appearance and the phenotype of antigen $\frac{\bar{s}}{7}$ presenting cells and mature macrophages together $\stackrel{\mathbb{Q}}{\circledR}$ with T lymphocytes suggests a cell mediated immune response. This is further supported by the strong $\vec{D}$ expression of the major histocompatibility complex class II molecules (HLA-DR) by bronchial epithelial $\vec{\omega}$ cells and by most infiltrating cells, and by the strong $\stackrel{\circ}{\circ}$ expression of CD7 antigen by most of the T cells. All $\vec{x}$ these phenomena are found in delayed hypersensitivity reactions. ${ }^{13}$

The predominance of suppressor-cytotoxic $\mathrm{T}$ cells $\stackrel{\infty}{\circ}$ over helper $T$ cells has also been observed in cryp- $\infty$ togenic fibrosing alveolitis, ${ }^{14}$ whereas in other chronic 음 inflammatory diseases, such as rheumatoid arthritis ${ }^{15} \longrightarrow$ and ulcerative colitis, ${ }^{16}$ the common pattern is the predominance of helper $\mathrm{T}$ cells.

The "vicious circle" hypothesis of the pathogenesis of bronchiectasis proposed by Cole ${ }^{1}$ suggests that $\vec{\oplus}$ initial damage to or underlying disease of the respiratory tract allows microbial colonisation as a result of reduced mucociliary clearance. The colonising organisms incite an inflammatory response that becomes chronic and causes tissue damage, which impairs bronchial mucociliary clearance still further. $\frac{\otimes}{\Phi}$ The results of our study are consistent with this $\stackrel{\square}{\square}$ hypothesis-the presence of a cell mediated immune $\overrightarrow{\overrightarrow{0}}$ response being one component of the bronchial 3 inflammation. The immune response we have identified within the lung in bronchiectasis may persist either because of constant antigenic stimulation by intrabronchial microrganisms or because of an $\frac{\mathrm{O}}{\mathrm{N}}$ underlying defect of the local immune response. To $\underset{x}{x}$ examine this possibility functional studies of the cells $\frac{5}{3}$ taking part in the immune response are required.

We are grateful to Drs C Steinfort, D Currie, E Sheffield, $M$ Spiteri, and $M$ Johnson and $\mathrm{Mr} P$ 의 Goldstraw for the supply of the specimens; to Dr B $\triangle$ Noble for valuable advice, and to Mrs M Whitney and Miss A Condez for technical support. J R L e $S$ is $N$ funded by the Brazilian Research Council (CNPq).

\section{References}

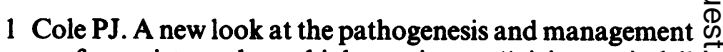
of persistent bronchial sepsis: a "vicious circle" ? hypothesis and its logical therapeutical connotations. $\frac{0}{0}$ In: Davies RJ, ed. Strategies for the management of $\underset{\mathbb{D}}{\mathbb{D}}$ chronic bronchial sepsis. Oxford: Medicine Publishing Foundation, 1984:1-20.

2 Cole PJ, Wilson R. Host-microbial interrelationships in 
respiratory infection. Chest 1989;95:217-21S.

3 Whitwell FA. A study of the pathology and pathogenesis of bronchiectasis. Thorax 1952;7:213-39.

4 Campbell DA, DuBois RM, Butcher RG, Poulter LW. Density of HLA-DR antigen expression on alveolar macrophages is increased in pulmonary sarcoidosis. Clin Exp Immunol 1986;65:165-71.

5 Munro CS, Mitchell DA, Poulter LW, Cole PJ. Early cellular responses to intradermal injection of Kveim suspension in normal subjects and those with sarcoidosis. J Clin Pathol 1986;39:176-82.

6 Crystal RG, Bitterman PB, Rennard SI, Hance AJ, Keogh BA. Interstitial lung disease of unknown cause. $N$ Engl J Med 1984;310:235-44.

7 Janossy G, Panayi, Duke O, Bofill M, Poulter LW, Goldstein G. Rheumatoid arthritis: a disease of Tlymphocyte immune regulation. Lancet 1981;ii:839-42.

8 Poulter LW, Chilosi M, Seymour GL, Hobbs S, Janossy G. Immunofluorescence membrane staining and cytochemistry, applied in combination for analysing cell interaction "in situ". In: Polak JM, Noorden S, eds. Immunocytochemistry: practical applications in pathology and biology. Bristol: Wright, 1983:233-48.

9 Janossy G, Bofill M, Poulter LW. Two-colour immunofluorescence: analysis of the lymphoid system with monoclonal antibodies. In: Polak JM, Noorden S, eds. Immunocytochemistry. Modern methods and applications. Bristol: Wright, 1986:438-55.

10 Bienenstock J. Mucosal immunological protection mechanisms in the airways. Eur $J$ Respir Dis 1986; 69(suppl 147):62-71.

11 Bienenstock J. Bronchus-associated lymphoid tissue. In: Bienenstock J, ed Immunology of the lung and upper respiratory tract. New York: McGraw Hill 1984: 96-117.

12 Bienenstock J, Befus D. Gut- and Bronchus-associated lymphoid tissue. Am J Anat 1984;170:437-45.

13 Unanue ER, Allen PM. The basis of the immunoregulatory role of macrophages and other accessory cells. Science 1987;236:551-7.
14 Kallenberg CGM, Schilizzi BM, Beaumont F, Poppema S, De Leij J, The TH. Expression of class II MHC antigens on alveolar epithelium in fibrosing alveolitis. Clin exp Immunol 1987;67:182-90.

15 Duke O, Panayi GS, Janossy G, Poulter LW. An immunohistological analysis of lymphocyte population and their microenvironment in the synovial membranes of patients with rheumatoid arthritis using monoclonal antibodies. Clin exp Immunol 1982;49: 22-30.

16 Poulter LW, Allison M, Richardson AT, Janossy G. The distribution of lymphocyte subset in inflammatory disease and reactive synovitis: a comparison. In: Mielants H, Veys EM, eds. Spondyloarthropaties: involvement of the gut. Amsterdam: Elsevier 1987: 213-20.

17 Evans RL, Wall DW, Platsourcas CD, et al. Thymusdependent membrane antigens in man: inhibition of cell-mediated lympholysis by monoclonal antibodies to the TH2 antigen. Proc Natl Acad Sci 1981;78:544-7.

18 Poulter LW, Duke O, Hobbs S, Raftery MJ, Janossy G. Activated T-lymphocytes of the synovial membrane in rheumatoid arthrytis and other arthropathies. Scand J Immunol 1985;22:683-90.

19 Janossy G, Prentice HG. T cell subpopulations, monoclonal antibodies and their therapeutic applications. Clin Haematol 1982;11:631-60.

20 Janossy G. Human Lymphocyte subsets: their tissue distribution. Progr Immunol 1984;5:1085-101.

21 Poulter LW, Collings LA, Tung KS, Waters MFA. Parasitism of antigen presenting cells in hyperbacillary leprosy. Clin Exp Immunol 1984;55:611-7.

22 Munro CS, Campbell DA, Collins LA, Poulter LW. Mononuclear antibodies distinguish macrophages and epithelioid cells in sarcoidosis and leprosy. Clin Exp Immunol 1987;68:282-7.

23 Collings LA, Tidman N, Poulter LW. Quantitation of HLA-DR expression by cells involved in the skin lesions of tuberculoid and lepromatous leprosy. Clin Exp Immunol 1985;61:58-60. 